\title{
SOCIAL RightS AND OBLIGATIONS: THE RELATIONSHIP BETWEEN CITIZENS AND THE Administration of Social LAW IN Poland
}

\author{
DOMINIKA CENDROWICZ*
}

\section{INTRODUCTION}

The subject of human social rights ${ }^{1}$ and the relationship occurring between the social rights to which a human being is entitled to and the obligations of the administration in the scope of their achievement constitute issues of special significance in contemporary Europe ${ }^{2}$. There are many reasons for this. Most of all, this results from historical experiences of European countries showing a certain regularity according to which, each time, the cause of social tensions and revolutionary outbreaks in the countries was fighting not only for freedom but also decent conditions of existence ${ }^{3}$. 'Awareness of this regularity's existence as well as the fear of the interstate social conflict of economic origin made the constitutions of European countries, established after the First World War, offer a wide

DOI: $10.1515 /$ wrlae-2015-0052

* PhD in Law, Assistant Professor at the Institute of Administrative Sciences, Faculty of Law, Administration and Economics, University of Wrocław; dominika.cendrowicz@,uwr.edu.pl

${ }^{1}$ Social rights are usually included in the human rights of second generation in the literature on the subject. They are understood as the so-called positive rights and named indicative rights' creating the sphere within which the state is ordered to act in order to fulfil them. When discussing the problems of social rights, one also considers the fact that these are specifically related to freedom and human personal rights. This relationship may be presented in the way that the achievement of social rights is a condition of using other rights and freedoms. This is the reason for an instrumental nature of social rights in relation to personal rights. However, lately, the former have started to perform an autonomous function. The fact that an autonomous function is attributed to social rights results from the process of expanding their range and the related state benefits. This phenomenon is visible in many European countries, including Poland, where among freedoms and social rights, the right to social security, together with social assistance, is of great significance. Monika Lewandowicz-Machnikowska, Regulacja prawna socjalnego wsparcia dla osób o niskich dochodach (E-Wydawnictwo. Prawnicza i Ekonomiczna Biblioteka Cyfrowa. Wydział Prawa, Administracji i Ekonomii Uniwersytetu Wrocławskiego 2013) 73; cf.: Jerzy Oniszczuk, Wolności i prawa socjalne oraz orzecznictwo konstytucyjne (Szkoła Główna Handlowa w Warszawie 2005).

${ }^{2}$ Włodzimierz Anioł, Polityka socjalna UE (Wydawnictwo Sejmowe 2003) 5.

3 Paweł Kuczma, 'Prawo do pomocy społecznej' in Mariusz Jabłoński (ed), Realizacja $i$ ochrona konstytucyjnych wolności $i$ praw jednostki $w$ polskim porzadku prawnym (EWydawnictwo. Prawnicza i Ekonomiczna Biblioteka Cyfrowa. Wydział Prawa, Administracji i Ekonomii Uniwersytetu Wrocławskiego 2014) 619. 
range of civil rights, including the category of social rights' ${ }^{4}$. On the other hand, guaranteeing social rights and their development in law became a rule after the Second World War with the noticed necessity of providing people with minimum living standards in order to arrange the harmonious development of a Europe wrecked by war. Then, social rights became a subject of regulations in the international law on a larger scale ${ }^{5}$. Undoubtedly, among the instruments of international law referring to social rights and issued after the Second World War, the Charter of the United Nations is of special significance. Its provisions have emphasised the relationship between the observance of human rights, including social rights, and the assurance of the world's peace. Internationally, the significance of the category of social rights is also visible in, enacted in 1966, the International Covenant on Economic, Social and Cultural Rights as well as the European Social Charter in which the idea of universal social rights occurs, and it is found in, among others, art 12 and 13 of the Charter ${ }^{6}$. On the other hand, as far as European legislation is concerned, the right to social security and social assistance has been confirmed in the Charter of Fundamental Rights of the European Union ${ }^{7}$.

\section{The Concept of Social Rights AND Social Benefits IN POLAND}

In Poland social rights are usually considered as constitutional rights $^{8}$. With regard to social constitutional rights, they are quite often considered to be personal rights. Particular laws provide further specification in this scope. Therefore, social rights may, and in many cases do, constitute the grounds for claims advanced by individuals against the state for attaining these rights. The category of social rights is in a close relationship with the notion of social benefits; that is, the benefits through which a state aims to ensure its citizens' social safety ${ }^{9}$. In the science of Polish law, social benefits, through which the state performs its social functions, are generally understood as kinds of gains obtained by an

\footnotetext{
${ }^{4}$ ibid [own translation from Polish].

5 ibid.

${ }^{6}$ European Social Charter established in Turin on 18 October 1961. It was amended by the Protocol amending the European Social Charter, drawn up in Turin on 21 October 1991.

${ }^{7}$ Art 34 of the Charter of Fundamental Rights of the European Union [2010] OJ of the EU C 83/389: 'The Union recognises and respects the entitlement to social security benefits and social services providing protection in cases such as maternity, illness, industrial accidents, dependency or old age, and in the case of loss of employment, in accordance with the rules laid down by Community law and national laws and practices.'

8 Cf.: Leon Wiśniewski, 'Pojęcie i konstrukcja prawna praw socjalnych' in Leon Wiśniewski (ed), Podstawowe prawa jednostki $i$ ich sądowa ochrona (Wydawnictwo Sejmowe 1997).

9 Iwona Sierpowska, 'Bezpieczeństwo socjalne jako kategoria dobra publicznego' in Marta Woźniak, Ewa Pierzchała (eds), Administracja dóbr i ustug publicznych w Polsce (Diffin 2013) 87 .
} 
individual from a state or territorial self-government ${ }^{10}$, and as all kinds of funds spent on an individual person's or a family's needs ${ }^{11}$. Discussing them in the categories of public goods is also significant here. Social benefits are financed with public funds. Most often, an individual receives them nonequivalently ${ }^{12}$, 'giving nothing in return' ${ }^{13}$. However, in the case of some benefits, this quality is subject to exception ${ }^{14}$.

\section{Sources of Social Rights and Social Benefits IN Poland}

The basic source of social rights in Poland is the Constitution ${ }^{15}$. Its second chapter, entitled: 'Human and Citizen's Freedoms, Rights and Duties' includes regulations concerning, among other things, social rights which satisfy the needs of an individual's economic security. The constitutional regulation of social rights causes the reduction of state's role in developing regulations of social benefits ${ }^{16}$. The Constitution defines the

${ }^{10}$ For instance, Grażyna Szpor, 'Korzystanie z dóbr publicznych' in Irena Lipowicz, Zygmunt Niewiadomski, Kazimierz Strzyczkowski, Grażyna Szpor (eds), Prawo administracyjne. Część materialna (Lexis Nexis 2004) 156.

${ }^{11}$ According to the concept of Herbert Szurgacz, formulated in the 90s of the 20th century, social benefits have common legal attributes and perform similar functions. According to this author, introducing them to the Polish legal order after 1989 was an effect of emergence of new social problems or intensification of the existing ones and that made one method of protection, recognised as irrational, be replaced with other method. This opinion, despite the unquestionable development of social rights and the related benefits, is still valid. Regardless of the changing names, content and replacement with other types of benefits or changing conditions and ways of their granting, social benefits have been still performing the same social function and have remained important to people using them. Herbert Szurgacz, Wstęp do prawa pomocy społecznej (Wydawnictwo Uniwersytetu Wrocławskiego 1992) 84 et seq.

12 Barbara Rysz-Kowalczyk (ed), Leksykon politologii społecznej (Aspra JR F.H.U. 2002) 208.

${ }^{13}$ Judgment of the District Administrative Court in Warsaw of 13 June 2006, I SA/Wa 79/06, CBOSA.

14 Iwona Sierpowska, Pomoc społeczna jako administracja świadczaca (Wolters Kluwer 2012) 199.

${ }^{15}$ The Constitution of the Republic of Poland of 2 April 1997 (Dziennik Ustaw - Official Journal of Laws of the Republic of Poland (hereinafter: Dz. U.) 1997, No 78, item 483 as amended), hereinafter: the Constitution.

${ }^{16}$ As Monika Lewandowicz-Machnikowska claims social benefits in Poland 'include (...) the right to social protection [thus, also to social assistance, DC] and other rights provided for by the Constitution as state's obligations, as the obligation to take actions within the scope of providing special protection in securing livelihood for the disabled, the obligation of pursuing the policy supporting the satisfaction of housing needs, the right of families in a difficult financial situation to a special assistance of the public authorities, the right to individual assistance for students in connection to providing equal access to education, as well as, the right of a child deprived of parental care to the care and assistance of the public authorities. When accepting the aforementioned standpoint of M. LewandowiczMachnikowska, one should simultaneously emphasise that the range of the individual's rights of a social nature is subject to frequent amendments. It is impossible to confine such living matter forced to react to changing social needs in one legally limited catalogue of benefits related to social rights. The social sphere of activity of a state and its administration is evolving and showing far-reaching quantitative and qualitative development within the scope of tasks referring to individual's social needs. Therefore, the types of social benefits have not been listed in the Constitution. This would be both impossible and misguided. Lewandowicz-Machnikowska (n 2) 59. 
extent of the ordinary legislator's discretion in this scope. Although, undoubtedly, the contents of legal regulations concerning social benefits are determined by the level of the state's economic capacity, their inclusion into the Constitution excludes them from an ad hoc political process of making decisions and imposes priorities in pursuing a social policy ${ }^{17}$. A hint concerning the method of pursuing a social policy and developing social law in legislation can be found in the decision of the Constitutional Tribunal of 23 March 1992, K 6/91 ${ }^{18}$, according to which the constitutional legislator, by legislating the citizens' right to the state's assistance through social insurance and assistance, allowed the legislator some leeway within the scope of its completion, namely, in relation to the definition of types of social benefits, forms of assistance, conditions of their acquirement and loss, amounts, granting procedures, etc. The only 'restraint' the legislator experiences in this scope is an obligation of development of social insurance referring also to 'extension' of different forms of social assistance ${ }^{19}$.

The fact that, in Poland, there are multiple laws regulating social benefits $^{20}$ is worth adding here. The Polish legal system within the area of social security is still (especially in comparison with the German system) somewhat unstructured. There are many legal instruments binding in Poland providing regulations on social benefits to which classification might be a challenge $^{21}$. These instruments fall within different domains of law: social security law, social law or administrative law. However, it seems that associating them with the sphere of administrative social law is the most appropriate; namely, these instruments involve social regulations and the administration's activity focused on tasks related to the provision of material living conditions in a society, through satisfying certain needs or creating specific social tools ${ }^{22}$. Nevertheless, this approach does not exclude either obvious relations and merging of different domains of law, or the possibility of including social benefits used to improve the existence of an individual to other domains of law. This shows the interdisciplinary character of the discussed issue and its numerous relationships with administrative law and the administration's tasks towards citizens.

\footnotetext{
${ }^{17}$ Lewandowicz-Machnikowska (n 2) 64.

18 The mentioned judgment referred to art $70 \mathrm{sec} 1$ of the invalid Constitution of the Republic of Poland enacted by Legislative Seym on 22 July 1952 (Dz. U. 1976, No 7, item 36 as amended).

${ }^{19}$ The decision of the Constitutional Tribunal of 23 March 1992, K 6/91, (1992) OTK ZU item 3.

${ }^{20}$ In Poland, the individual's social rights are expanded in detail in numerous laws whose provisions are often dependent on the changing state's policy in the domain of security of citizen's social rights. See: Béla Tomka, 'Social Policy in East Central Europe: Major Trends in the 20th Century' in Alfio Cerami and Peter Vanhuysee, (eds), Post-Communist Welfare Pathways: Theorizing Social Policy Transformations in Central and Eastern Europe (Basingstoke: Palgrave Macmillan 2009) 17-34; Mitchell A. Orenstein, Martine R. Haas, 'Globalization and the Future of Welfare States in the Post-Communist East-Central European Countries' in Miguel Glatzer, Dietrich Rueschemeyer (eds), Globalization and the Future of the Welfare State (University of Pittsburgh Press 2005) 131-151.

${ }^{21}$ Lewandowicz-Machnikowska (n 2) 28.

22 Jan Boć in Jan Boć (ed), Nauka administracji (Kolonia Limited 2013) 234. See also.: Tadeusz Kuta 'Zaspokajanie potrzeb socjalno-bytowych i oświatowo-kulturalnych obywateli' in System prawa administracyjnego, vol IV (Ossolineum 1980) 111.
} 


\section{The Right to Social Assistance as one OF THE INDIVIDUAL'S Social Right IN POLAND}

The right to social assistance is one of the key social rights of the individual with regard to Polish law ${ }^{23}$. It was derived from art $67 \mathrm{sec} 2$ of the Constitution of the Republic of Poland and elaborated in the Social Assistance Act of 12 March $2004^{24}$. Regulated by its provisions, social assistance is an institution of the state's social policy aimed at enabling individuals and families to overcome difficult life situations which they cannot overcome themselves solely by the use of their own powers, resources and abilities ${ }^{25}$. The essence of social assistance financed with public funds comes down to satisfaction of only basic needs, that is, those with which one maintains the minimum of human living standards ${ }^{26}$.

In the Social Assistance Act, the state determines the limits of its obligations towards the citizens ${ }^{27}$ within the scope of social assistance. Here, one should emphasise that the mentioned act is a legal regulation of the so-called social assistance sensu stricto. Simultaneously, the Social Assistance Act is not a lex specialis act in relation to other legal acts governing other forms of social benefits than those provided for in the Social Assistance Act. The Polish social assistance is characterised by diverse and coexistent benefits organised with an administrative apparatus composed of public administration authorities and non-public bodies. Within this system, there are the specialised service providers led by social workers who are direct task executors within the area of social assistance ${ }^{28}$. Social assistance benefits are financed by public resources ${ }^{29}$.

The ground rule of Polish social assistance is the principle of subsidiarity provided for by art $2 \mathrm{sec} 1$ of the Social Assistance $\mathrm{Act}^{30}$. This is compatible with Council Recommendation 92/441/EEC of 24 June 1992 on common criteria concerning sufficient resources and social assistance in social protection systems, which unequivocally formulates the principle of subsidiarity of social assistance benefits ${ }^{31}$ meaning a ban on doing things for

\footnotetext{
23 Adam Błaś, 'Zagadnienie zakresu zadań socjalnych administracji publicznej we współczesnym państwie liberalnym' in Małgorzata Giełda, Renata Raszewska-Skałecka (eds), Administracja publiczna wobec wyzwań i oczekiwań społecznych (E-Wydawnictwo. Prawnicza i Ekonomiczna Biblioteka Cyfrowa. Wydział Prawa, Administracji i Ekonomii Uniwersytetu Wrocławskiego 2015) 18.

${ }^{24}$ Polish Social Assistance Act of 12 March 2004 (Dz. U. 2016, item 930). Further: Social Assistance Act.

${ }^{25}$ Art 2 sec 1 of Social Assistance Act.

${ }^{26}$ Sierpowska (n 10) 83.

27 Sierpowska (n 15) 355.

28 Alina Miruć, 'O istocie pomocy społecznej' (2006) 4(5) Administracja. Teoria. Dydaktyka. Praktyka 39-40.

${ }^{29}$ ibid 40.

${ }^{30}$ Karolina Wrona, Zasada subsydiarności w sprawach o świadczenia z pomocy społecznej w praktyce Naczelnego Sadu Administracyjnego (2004) 4(16) 16 et seq.

${ }^{31}$ Herbert Szurgacz, 'Regulacje prawnomiędzynarodowe w zakresie pomocy społecznej' in Bernd von Maydell, Tadeusz Zieliński (eds), Lad społeczny w Polsce i Niemczech na tle jednoczacej się Europy. Księga pamiątkowa poświęcona Czesławowi Jackowiakowi (Wydawnictwo Polsko-Niemieckie 1999) 513.
} 
an individual (family) when he can cope with the situation on his own ${ }^{32}$. Within the Polish legislation, the principle of subsidiarity in social assistance is related to the area of legal regulation concerning the division of tasks and competences between bodies of public authorities in the state (that is, between bodies of territorial self-government and governmental administration) and is of considerable significance for relationships taking place between the public administration and an individual ${ }^{33}$.

Here, one should note a similarity occurring between the Polish and German social assistance systems. According to S. Nitecki, social assistance in Germany constitutes a foundation system for social security, playing a part of the so-called lower net picking up the cases which 'have fallen through the mesh of the upper net'. One of the social assistance tasks in Germany is providing support in particularly difficult situations for everyone who has not used it on accounts of special systems of social security and assistance in personal development, e.g. in relation to the disabled or maladaptive ${ }^{34}$. In many regards, this understanding of social assistance is also adopted in Poland.

\section{Social Assistance Benefits according to the Social Assistance ACT}

With regard to social assistance benefits, it should be emphasised that the Social Assistance Act in its art 36 divides them dichotomously into cash and non-cash benefits ${ }^{35}$. The catalogue of benefits provided for by the Social Assistance Act is relatively developed and diverse and, additionally, each benefit type includes a different catalogue of conditions determining its granting $^{36}$. The cash benefits include (Art. $36 \mathrm{sec} 1$ of the Social Assistance Act): permanent, periodical, single purpose, and special needs allowance, allowance or loan granted to reach financial independence, assistance to reach financial independence and continue education, cash benefits for livelihood and covering costs of Polish language learning for foreigners ${ }^{37}$. Among the non-cash benefits, which are not always classified as social benefits, there are (Art. $36 \mathrm{sec} 2$ of the Social Assistance Act): social work, funded ticket, health and social insurance contributions, aid in kind including the one to reach financial independence, funeral allowance, specialist counselling, crisis intervention, shelter, meal, indispensable

\footnotetext{
32 Józef Jończyk, Prawo zabezpieczenia społecznego, ubezpieczenia społeczne $i$ zdrowotne, bezrobocie i pomoc społeczna (Zakamycze 2001) 394.

33 Alina Miruć, 'Zasada pomocniczości w prawie pomocy społecznej' (2008) 3 Administracja. Teoria. Dydaktyka. Praktyka 28.

34 Stanisław Nitecki, Prawo pomocy społecznej $w$ polskim systemie prawnym (Wolters Kluwer 2008) 31.

${ }^{35}$ Pursuant to art 7 of the Social Assistance Act, these benefits are granted, among others, due to poverty, orphanhood, homelessness, unemployment, disability, long-term or severe disease, domestic violence, the need of protecting victims of human trafficking, the need of protecting motherhood or families with many children.

${ }^{36} \mathrm{Cf}$. Wojciech Maciejko, Instytucje pomocy społecznej (Lexis Nexis 2008) 67-204.

${ }^{37}$ Sierpowska (n 10) 87.
} 
clothing, home care services, care services in assistance centres and crisis accommodation for families, specialist home care services and specialist care services in assistance centres, supervised apartment, stay and services in residential homes, assistance in obtaining proper accommodation conditions including a supervised apartment, assistance in obtaining employment, in-kind assistance for persons supported for independent living.

When describing benefits provided for by the Social Assistance Act, it should be distinctly stressed that the aforementioned catalogue of benefits displays adjustment to legal solutions adopted in the EU. Their manifestation is provision of the right to social assistance in relation to the EU member states' citizens and foreigners meeting requirements defined by the Social Assistance Act, right to cash assistance for foreigners as well as provisions concerning benefits as social work, career counselling and crisis intervention $^{38}$. Apart from that, the structure of benefits subject to regulations of the Social Assistance Act satisfies the requirements of aforementioned Council Recommendation 92/441/EEC of 24 June 1992 on common criteria concerning sufficient resources and social assistance in social protection systems ${ }^{39}$.

\section{Social Benefits in Poland outside the Social Assistance ACT}

However, as mentioned previously, the social benefits system in Poland does not include the benefits provided for by the Social Assistance Act solely. It is much more developed and it is not regulated by a single legal instrument. Benefits from outside the Social Assistance Act are very diverse. The facts distinguishing them from the benefits included in the Social Assistance Act are, among others, that they are granted for the purpose of providing specific support for individuals or families, and that the principle of subsidiarity, essential to the Social Assistance Act, is not applicable here. Moreover, these benefits, in contrast to many benefits from the Social Assistance Act, involve a claim ${ }^{40}$. These are granted when a person meets the particular criteria laid down by the laws. In the science of law, these are classified as social assistance sensu largo or social support assistance $^{41}$

Among the social assistance benefits in their broad sense, especially significant are those focused on supporting a family. According to art $71 \mathrm{sec}$ 1 of the Constitution 'the State, in its social and economic policy, shall take into account the good of the family', and also 'families, finding themselves in difficult material and social circumstances [...] shall have the right to special assistance from public authorities'. This provision expresses one of the most significant state's obligations towards the citizens, namely, the

\footnotetext{
${ }^{38}$ Sierpowska (n 15) 25.

${ }^{39}$ Szurgacz (n 12) 515. This remark was made in relation to the Act of 27 November 1990 on social assistance. However, this can be also referred to the Social Assistance Act.

${ }^{40}$ Lewandowicz-Machnikowska (n 2) 27.

${ }^{41}$ For instance Monika Lewandowicz-Machnikowska, Stanisław Nitecki, and, lately, Iwona Sierpowska.
} 
obligation to actively pursue pro-family social policy aiming at supporting families in difficult material and social situations ${ }^{42}$. The manifestations of respecting the constitutional norm are regulations dealing with social protection of a family in law. Therefore, Poland has a relatively developed catalogue of benefits focused on supporting poor families.

In this scope, a relatively new social benefit in Poland is a childsupport benefit introduced by the Act of 11 February 2016 on state aid in raising children ${ }^{43}$. The aim of this benefit is partially taking-over of costs related to raising a child, including taking care of him/her and satisfying his/her life's needs ${ }^{44}$. This benefit is due in the amount of PLN 500 a month, regardless of family income and each second and subsequent child is entitled to it until he/she turns 18 . There is also a possibility of receiving this benefit for the first child. This is possible when the family income per person does not exceed PLN 800 a month whereas the Council of Ministers may, by way of regulation, increase these amounts taking the projected general annual average consumer price index adopted in a budget act for a particular calendar year into consideration.

Despite many advantages of the child-support benefit, when one considers the fact that the range and amount of social assistance for citizens should also take into account financial possibilities of the state, it raises doubts in the context of not including its amount to the income entitling an individual to receive cash benefits from the Social Assistance Act ${ }^{45}$. Further doubts are raised by the regulation of art $5 \sec 3$ of Act on state support in raising children, according to which the first child is entitled to this benefit when family income per person does not exceed PLN 800 (in the case of the family raising a disabled child it is PLN 1.200). Taking the principle of social justice $^{46}$ into consideration, this means that a family or a single parent of one child will not receive the child-support benefit if their income exceeds the amount of PLN 800 by few groszes. On the other hand, a person or a family raising more than one child will receive this support even when their income exceeds PLN 800 even several times. Undoubtedly, the current solution in this scope requires specific amendments to the act on state support in raising children concerning the conditions of granting the childsupport benefit to single parents and families raising one child.

The system of Polish law, apart from the child-support benefit, offers other legal regulations dedicated to the social protection of a family which encourages starting a family, protects it against discrimination, provides it with proper medical care and, finally, provides it with financial support, and this especially concerns families with low incomes, large families and those raising disabled children ${ }^{47}$. Most of all, this is family allowance aimed at a

\footnotetext{
${ }^{42}$ Karolina Stopka, Zasada subsydiarności w prawie pomocy społecznej (Diffin 2009) 148.

43 The Act of 11 February 2016 on state aid in raising children (Dz. U. 2016, item 195). Hereinafter referred to as: Act on state support in raising children.

${ }^{44}$ To a certain degree it corresponds with a family allowance.

${ }^{45}$ Art 8 sec 3 of the Social Assistance Act.

${ }^{46}$ Cf.: John Rawls, Teoria sprawiedliwości (PWN 1994) passim; Friedrich A. Hayek, 'Fikcja sprawiedliwości społecznej' in Teksty liberalne (DiG 1993), passim; Zygmunt Ziembiński, O pojmowaniu sprawiedliwości (Instytut Wydawniczy Daimonion 1992).

${ }^{47}$ Sierpowska (n 15) 211.
} 
partial take-over of costs related to raising a child ${ }^{48}$ and supplements to the family allowance ${ }^{49}$. Apart from the family allowance and supplements to it, the Polish law provides different kinds of carer's benefits. The aim of these benefits is 'partial taking-over of costs related to taking care of an old or disabled family member'. These benefits include attendance benefit and attendance allowance: the former is granted to partially take over the costs resulting from the necessity of providing care and assistance to another person in relation to his/her inability of leading an independent life, and the latter due to resigning from job or other paid employment. Apart from that, the Polish law also provides assistance to single parents. This support is granted on the basis of state maintenance payment system regulated by the Act of 7 September 2007 on supporting individuals entitled to maintenance payments ${ }^{50}$. The state support for individuals finding themselves in a difficult financial situation due to their inability of enforcing maintenance payment results from the constitutional principle of subsidiarity which imposes an obligation upon the state of supporting poor people who are unable to satisfy their needs independently and do not receive due support from individuals liable for maintenance payment. This support should not be associated with actions focused on increasing liability of people liable for maintenance payment ${ }^{51}$.

Apart from the benefits described above, other social forms of state support in Poland are worth adding here. These can be found, among others, in the Act of 13 June 2003 on social employment ${ }^{52}$, the Act of 9 June 2011 on supporting a family and kinship care ${ }^{53}$, the Act of 20 April 2004 on promotion of employment and institutions of labour market ${ }^{54}$, Act of 21 June 2001 on residential allowance ${ }^{55}$ (residential allowance), the Act of 7 September 1991 on the education system ${ }^{56}$ (school scholarship and school

\footnotetext{
${ }^{48}$ Family allowance is aimed to partially taking over of costs related to supporting a child. Parents, one of the parent, children's legal and actual guardian as well as a student are entitled to the allowance and supplements to it. Cf. art 4 sec 1 of Act of 28 November 2003 on family allowances (Consolidated text Dz. U. 2015, item 114 as amended). Hereinafter referred to as: Act on family allowances.

${ }^{49}$ These are childbirth supplement, child care leave supplement, supplement for education and rehabilitation of a disabled child as well as supplement for starting a school year, supplement for starting school outside the place of residence, as well as different kinds of supplements for singles and childbirth allowance aid.

50 Act of 7 September 2007 on the assistance of people entitled to maintenance payments (Consolidated text Dz. U. 2016, item 169 as amended). Hereinafter mentioned as: Act on the assistance of people entitled to maintenance payment.

51 Cf.: The Preamble to the Act on the assistance of people entitled to maintenance payment.

52 Act of 13 June 2003 on social employment (Consolidated text Dz. U. 2011, No 43, item 225 as amended).

${ }^{53}$ Act of 9 June 2011 on supporting a family and kinship care (Consolidated text Dz. U. 2015, item 332 as amended).

${ }^{54}$ It is about the unemployment benefit provided for by art $71 \mathrm{sec} 1$ item $2 \mathrm{c}$ of the Act of 20 April 2004 on the promotion of employment and institutions of labour market (Consolidated text Dz. U. 2016, item 625 as amended). Apart from that, the unemployed may be granted support in form of benefits from the Social Assistance Act, social work or funded ticket.

${ }^{55}$ Act of 21 June 2001 on residential allowance (Consolidated text Dz. U. 2013, item 966 as amended).

${ }^{56}$ Act of 7 September 1991 on the education system (Consolidated text Dz. U. 2004, No 256, item 2572 as amended).
} 
benefit). The mentioned exemplary benefits are very diverse and their legal regulation can be found in numerous instruments and, as such, providing their detailed description would go beyond the frameworks of this article.

\section{Social Administration Obligations in Poland}

Undoubtedly, this vast catalogue of the individual's social rights in Poland is related to obligations of the state and its administration defined in the right to their accomplishment. Development, financing and granting of social benefits are the tasks of the state and public administration authorities acting on its behalf or on the behalf of territorial self-governments. Their enforcement takes place according to the procedure of control over the activity of the government and authorities obliged to their fulfilment. The sanction for a failure to complete them is legal liability of individuals holding public offices ${ }^{57}$. Assigning tasks from the social sphere in the form of obligatory own tasks (in the case of commune), own tasks or commissioned tasks, to territorial self-government authorities prejudges the obligation of their execution. This means that administration authorities cannot cease to execute allowance tasks even despite their unprofitability ${ }^{58}$. The legal obligation of completing the tasks reinforces the social position and security of Polish citizens.

Most of the social benefits in Poland are granted and implemented in communes. This enables one to offer a thesis concerning the existence of a local social administration structure within the entities of territorial selfgovernment. Its functioning and constant development is the result of pursuing the principle of subsidiarity in a social life manifesting itself in the fact that an individual should seek the help of the public authority of his/her place of residence ${ }^{59}$. In Poland, the self-government units are basic entities obliged to execute tasks related with the achieving of the individual's social rights $^{60}$, as they are the social administration entities ${ }^{61}$. Assigning the tasks of a social nature to the territorial self-government unit corresponds with the standpoint according to which its 'position (...) as an administration entity

\footnotetext{
57 Tadeusz Zieliński, Czas prawa i bezprawia. Myśli niepokorne kustosza praw (Dom Wydawniczy ABC 1999) 127.

${ }^{58} \mathrm{Cf}$. Jolanta Blicharz's discussion on the legal structure of a public task. Jolanta Blicharz, 'Zakres znaczeniowy pojęcia zadanie publiczne' (2005) LXXI, Przegląd Prawa i Administracji.

${ }^{59}$ Cf. Stanisław Fundowicz, 'Administracja bliska ludziom i bliska ludzi' in Prawo do dobrej administracji (Cardinal Stefan Wyszyński University in Warsaw 2003) passim.

${ }^{60} \mathrm{Cf}$. for instance arts 17 and 18 of the Social Assistance Act, art 2 in relation to art 3 item 11 of the Act on family allowances, art 9a of the Act on residential allowances, art 31 in relation to 2, item 9 and 10 of the Act on the assistance of people entitled to maintenance payment, art 29 item 1 in relation to art 2, item 11 of the Act on state support in raising children.

${ }^{61}$ Territorial self-government is responsible for executing tasks for the interest of local and regional communities. The catalogues of tasks assigned to a territorial self-government are developed and also includes the tasks of social sphere. Cf. art $7 \mathrm{sec} 1$ of the Act of 8 March 1990 on commune self-government (Dz. U. 2016, item 446); art $4 \mathrm{sec} 1$ of the Act of 5 June 1998 on district self-government (Dz. U. 2016 item 814); art 14 sec 1 of the Act of 5 June 1998 on voivodeship self-government (Dz. U. 2016, item 486.
} 
providing services have not been questioned in the doctrine (of law - DC] for years. The self-government has been perceived [in it - DC] as a subject of satisfying basic needs within the scope of social assistance, education, preschool or primary school education, but also - referring to the classic construction of Ernst Forsthoff ${ }^{62}$ - supplying individuals with water, heat and electricity ${ }^{63}$.

Social administration, when deciding on granting or refusing to grant a benefit, acts within and on the basis of the law. 'The whole [of its DC] actions (...) is governed by the law. The same is true for the instruments thanks to which it can operate ${ }^{, 64}$. The cash benefits are granted through an administrative procedure with the use of the provisions of the Code of Administrative Procedure ${ }^{65}$. However, there are exceptions to this rule. These concern benefits provided for by the Social Assistance Act as loan, lending for use, funded ticket, crisis intervention, shelter, meal, clothing or funeral. To grant them, the administration uses civil law contracts $^{66}$ or factual administrative activities. This results from the nature of these benefits and reasons for their granting.

The fact that social benefits in Poland are granted pursuant to an administrative decision should be assessed positively. The expectations of beneficiaries in their relationships with the administration are focused on protection of their legal interests against unfavourable or illegal actions of the social assistance administration ${ }^{67}$. In order to meet these expectations, the legislator has introduced a vast catalogue of legal measures used in administrative procedures before the entities of social assistance. The 'resources' of legal measures to be used by the social assistance beneficiaries in Poland ensure realisation of the guarantee of these rights' protection. This constitutes a mechanism of multiple functions as: preventive, reviewing, protective and reference functions ${ }^{68}$.

\footnotetext{
${ }^{62}$ Cf.: Ernst Forsthoff, Die Verwaltung als Leistungsträger (Kohlhammer 1938).

${ }^{63}$ Irena Lipowicz, 'Samorząd terytorialny jako podmiot administracji świadczącej' (2015) 3 Ruch Prawniczy, Ekonomiczny i Socjologiczny 115.

${ }^{64}$ Jerzy Starościak, 'Prawne formy i metody działania administracji' in Teresa Rabska, Jerzy Łętowski (eds), System prawa administracyjnego, vol 3 (Ossolineum 1978) 39.

${ }^{65}$ Cf. Małgorzata Jaśkowska, 'Wpływ zmian w k.p.a. na sferę praw i wolności jednostki' in Teresa Górzyńska, Grzegorz Sibiga, Mateusz Błachucki (eds), Analiza i ocena zmian Kodeksu postępowania administracyjnego w latach 2010-2011 (Naczelny Sąd Administracyjny 2012).

66 Alina Miruć, 'Umowy cywilnoprawne ze świadczeniobiorcami w działaniach administracji pomocy społecznej’ in Sławomir Wrzosek and others (eds), Współzależność dyscyplin badawczych w sferze administracji publicznej (CH Beck 2010) 110-111.

67 Ewa Pierzchała, 'Standardy funkcjonowania administracyjnych środków prawnych w postępowaniu przed organami pomocy społecznej' in Jolanta Blicharz, Lidia KlatWertelecka, Edyta Rutkowska-Tomaszewska (eds), Ubóstwo w Polsce (E-Wydawnictwo. Prawnicza i Ekonomiczna Biblioteka Cyfrowa. Wydział Prawa, Administracji i Ekonomii Uniwersytetu Wrocławskiego 2014) 121.

${ }^{68}$ ibid.
} 


\section{CONCLUSION}

To conclude the above discussion, it should be once again emphasised that the issue of social rights and their accomplishment has a prominent place not only in social awareness but also within the social policy of the state. Most of all, this results from the essence of the discussed category of rights and related benefits through which the state provides its citizens with dignified living conditions, obviously, to the extent that resources allow. Therefore, social rights and the related benefits play a significant part according to the society's perception. The catalogue of social benefits found in Poland is relatively developed and characterised by a certain variability resulting from the fact that the matters of social assistance constitute an element of changing social policy of the state. This lack of permanency of regulations related to social benefits is also influenced by the fact that Polish social law has not been codified. It is difficult to embrace such a variable legal matter depending on the state's changing social policy with a legal instrument of the code's importance. The nearness of social assistance administration in relation to their place of residence is very important to citizens in the context of their contact with this administration. This is an expression of the principle of subsidiarity in a public sphere. However, much more important is attributing the legal obligation of social task execution to the social assistance administration in Poland, as well as creating legal protection of social rights for citizens which is most clearly expressed by their relation with the social assistance administration within the law.

\section{References}

Anioł Włodzimierz, Polityka socjalna UE (Wydawnictwo Sejmowe 2003) Blicharz Jolanta, 'Zakres znaczeniowy pojęcia zadanie publiczne' (2005) LXXI Przegląd Prawa i Administracji

Błaś Adam, 'Zagadnienie zakresu zadań socjalnych administracji publicznej we współczesnym państwie liberalnym' in Małgorzata Giełda, Renata Raszewska-Skałecka (eds), Administracja publiczna wobec wyzwań $i$ oczekiwań spolecznych (E-Wydawnictwo. Prawnicza i Ekonomiczna Biblioteka Cyfrowa. Wydział Prawa, Administracji i Ekonomii Uniwersytetu Wrocławskiego 2015)

Boć Jan in Boć Jan (ed), Nauka administracji (Kolonia Limited 2013)

Forsthoff Ernst, Die Verwaltung als Leistungsträger (Kohlhammer 1938)

Fundowicz Stanisław, 'Administracja bliska ludziom i bliska ludzi' in Prawo do dobrej administracji (Cardinal Stefan Wyszyński University in Warsaw 2003)

Hayek Friedrich A., 'Fikcja sprawiedliwości społecznej' in Teksty liberalne (DiG 1993)

Jaśkowska Małgorzata, 'Wpływ zmian w k.p.a. na sferę praw i wolności jednostki’ in Teresa Górzyńska, Grzegorz Sibiga, Mateusz Błachucki (eds), 
Analiza i ocena zmian Kodeksu postępowania administracyjnego $w$ latach 2010-2011 (Naczelny Sąd Administracyjny 2012)

Jończyk Józef, Prawo zabezpieczenia społecznego, ubezpieczenia społeczne i zdrowotne, bezrobocie i pomoc społeczna (Zakamycze 2001)

Kuczma Paweł, 'Prawo do pomocy społecznej' in Mariusz Jabłoński (ed), Realizacja i ochrona konstytucyjnych wolności i praw jednostki w polskim porzadku prawnym (E-Wydawnictwo. Prawnicza i Ekonomiczna Biblioteka Cyfrowa. Wydział Prawa, Administracji i Ekonomii Uniwersytetu Wrocławskiego 2014)

Kuta Tadeusz' Zaspokajanie potrzeb socjalno-bytowych i oświatowokulturalnych obywateli' in System prawa administracyjnego, vol IV (Ossolineum 1980)

Lewandowicz-Machnikowska Monika, Regulacja prawna socjalnego wsparcia dla osób o niskich dochodach (E-Wydawnictwo. Prawnicza i Ekonomiczna Biblioteka Cyfrowa. Wydział Prawa, Administracji i Ekonomii Uniwersytetu Wrocławskiego 2013)

Lipowicz Irena, 'Samorząd terytorialny jako podmiot administracji świadczącej' (2015) 3 Ruch Prawniczy, Ekonomiczny i Socjologiczny Maciejko Wojciech, Instytucje pomocy społecznej (Lexis Nexis 2008) Miruć Alina, 'O istocie pomocy społecznej' (2006) 4(5) Administracja. Teoria. Dydaktyka. Praktyka

Miruć Alina, 'Umowy cywilnoprawne ze świadczeniobiorcami w działaniach administracji pomocy społecznej' in Sławomir Wrzosek and others (eds), Wspótzależność dyscyplin badawczych $w$ sferze administracji publicznej (CH Beck 2010)

Miruć Alina, 'Zasada pomocniczości w prawie pomocy społecznej' (2008) 3 Administracja. Teoria. Dydaktyka. Praktyka

Nitecki Stanisław, Prawo pomocy społecznej w polskim systemie prawnym (Wolters Kluwer 2008)

Oniszczuk Jerzy, Wolności i prawa socjalne oraz orzecznictwo konstytucyjne (Szkoła Główna Handlowa w Warszawie 2005)

Orenstein Mitchell A., Martine R. Haas, 'Globalization and the Future of Welfare States in the Post-Communist East-Central European Countries' in Miguel Glatzer, Dietrich Rueschemeyer (eds), Globalization and the Future of the Welfare State (University of Pittsburgh Press 2005)

Pierzchała Ewa, 'Standardy funkcjonowania administracyjnych środków prawnych w postępowaniu przed organami pomocy społecznej' in Blicharz Jolanta, Klat-Wertelecka Lidia, Rutkowska-Tomaszewska Edyta (eds), Ubóstwo w Polsce (E-Wydawnictwo. Prawnicza i Ekonomiczna Biblioteka Cyfrowa. Wydział Prawa, Administracji i Ekonomii Uniwersytetu Wrocławskiego 2014)

Rawls John, Teoria sprawiedliwości (PWN 1994)

Rysz-Kowalczyk Barbara (ed), Leksykon politologii społecznej (Aspra JR F.H.U. 2002)

Sierpowska Iwona, 'Bezpieczeństwo socjalne jako kategoria dobra publicznego' in Woźniak Marta, Pierzchała Ewa (eds), Administracja dóbr $i$ ustug publicznych w Polsce (Diffin 2013)

Sierpowska Iwona, Pomoc społeczna jako administracja świadczaca (Wolters Kluwer 2012) 
Starościak Jerzy, 'Prawne formy i metody działania administracji' in Teresa Rabska, Jerzy Łętowski (eds), System prawa administracyjnego, vol III (Ossolineum 1978)

Stopka Karolina, Zasada subsydiarności $w$ prawie pomocy społecznej (Diffin 2009)

Szpor Grażyna, 'Korzystanie z dóbr publicznych' in Irena Lipowicz, Zygmunt Niewiadomski, Kazimierz Strzyczkowski, Grażyna Szpor (eds), Prawo administracyjne. Część materialna (Lexis Nexis 2004)

Szurgacz Herbert, 'Regulacje prawnomiędzynarodowe w zakresie pomocy społecznej' in Maydell Bernd von, Zieliński Tadeusz (eds), Ład społeczny w Polsce $i$ Niemczech na tle jednoczacej się Europy. Księga pamiatkowa poświęcona Czesławowi Jackowiakowi (Wydawnictwo Polsko-Niemieckie 1999)

Szurgacz Herbert, Wstep do prawa pomocy społecznej (Wydawnictwo Uniwersytetu Wrocławskiego 1992)

Tomka Béla, 'Social Policy in East Central Europe: Major Trends in the 20th Century' in Cerami Alfio and Vanhuysee Peter (eds), Post-Communist Welfare Pathways: Theorizing Social Policy Transformations in Central and Eastern Europe (Basingstoke: Palgrave Macmillan 2009)

Wiśniewski Leon, 'Pojęcie i konstrukcja prawna praw socjalnych' in Wiśniewski Leon (ed), Podstawowe prawa jednostki i ich sqqdowa ochrona (Wydawnictwo Sejmowe 1997)

Wrona Karolina, Zasada subsydiarności $w$ sprawach o świadczenia $z$ pomocy społecznej w praktyce Naczelnego Sadu Administracyjnego (2004) $4(16)$

Zieliński Tadeusz, Czas prawa $i$ bezprawia. Myśli niepokorne kustosza praw (Dom Wydawniczy ABC 1999)

Ziembiński Zygmunt, $O$ pojmowaniu sprawiedliwości (Instytut Wydawniczy Daimonion 1992) 